\title{
Comparison of Clinical and Sociodemographic Characteristics of Patients with Schizophrenia Treated Stationary and at Day Hospital
}

\author{
Ivana Blažinović ${ }^{1}$, Ivona Orlović ${ }^{1}$, Dalibor Karlovićc ${ }^{1,2}$, \\ Vjekoslav Peitl ${ }^{1,2}$ \\ ${ }^{1}$ Department of Psychiatry, University Hospital Center Sestre Milosrdnice, Zagreb, Croatia, \\ ${ }^{2}$ Catholic University of Croatia, Zagreb, Croatia
}

\begin{abstract}
The contemporary concept of treating schizophrenia tends to achieve functional remission, reducing the number and length of hospitalizations and improving the quality of life of patients. The aim of this study was to identify and compare the sociodemographic and clinical characteristics of patients with schizophrenia treated stationary and those treated at Day Hospital. This study, with the four month time interval, randomly included 60 participants with schizophrenia aged 18 to 55, who were divided into two groups. First group of 30 participants was treated only stationary, and the other 30 participants were treated only at Day Hospital. Each participant completed a sociodemographic and clinical characteristics questionnaire which was created for the purpose of this research. The results showed that participants treated at Day Hospital are younger, have a higher education level, and are more capable of working and functioning adequately. They are also more likely to receive psychiatric treatment from the early stages of their illness. Furthermore, participants treated in the Day Hospital setting have been less frequently hospitalized due to their illness (fewer acute episodes) than inpatients, which was statistically significant $(t=3,763 ; p=0,001)$, as a consequence of which they have a longer remission periods. This could contribute to better personal and social functioning, as well as to a better management of daily life, and thus implies a higher level of life quality compared to the inpatients.
\end{abstract}

Key words: schizophrenia; day care, medical; inpatients; psychotherapy, group

Copyright @ 2019 KBCSM, Zagreb

e-mail: alcoholism.kbcsm@gmail.com•www.http://apr.kbcsm.hr

\section{Introduction}

The modern concept of schizophrenia emphasizes the outcome of the disease,

Correspondence to: Vjekoslav Peitl, MD, PhD, Department of Psychiatry, University Hospital Centre Sestre milosrdnice, Vinogradska c. 29, 10000 Zagreb, Croatia

E-mail: vjekoslav.peitl@gmail.com where the focus of interest has shifted from reducing psychotic symptoms (symptomatic remission) to achieving better functioning (functional recovery and relapse prevention), reducing the number and duration of hospitalizations and improving the quality of life of patients [1,2]. For this purpose, it becomes apparent that we need to take a closer look at 
various sociodemographic and clinical characteristics of inpatients and those patients with schizophrenia treated at the Day Hospital.

The purpose of inpatient schizophrenia treatment mostly revolves around swift management of its acute phase through continuous observation of the patients functioning, along with adequate symptoms and side effects control. The most common indications for hospitalization of patients with schizophrenia are psychotic decompensation, the presence of suicidal ideation and risk, agitation at high risk for aggression, the development of certain acute side effects to psychopharmacotherapy, and in some case a social indication [3]. The goal of inpatient treatment is to stabilize the patient with psychopharmaceuticals and socio-therapeutic treatments and ultimately to recover them to the level of functionality that would allow further treatment via a Day Hospital or an outpatient form of treatment, for both of which a significantly higher level of insight and compliance is needed [4]. After inpatient psychiatric stabilization, the patient is admitted to a therapeutic community within the framework of socio-therapy and psychotherapy programs with the implementation of psychosocial interventions integrated with psychopharmacotherapy [5,6]. After hospital discharge, treatment continues in the outpatient setting, with regular psychiatric check-ups and sometimes as a weekly group therapy. However, some patients continue their treatment through the Day Hospital setting (partial hospitalization), as a more intensive form of multidisciplinary treatment than outpatient care $[7,8]$.

Such partial hospitalization program involves a Day Hospital for schizophrenic patients, which combines medications for the control of symptoms along with immersion of the patients in a social milieu through a different group therapy programs. The main purpose of the Day Hospital is to enable patients to understand, regulate and control their symptoms with the aim of avoiding future decompensations and psychiatric hospitalizations, that is, achieving rehabilitation and functionality. Accordingly, the patient remains involved in his / her environment, family and wider community, while staying in the hospital during the morning, taking part in group therapy under the guidance of an interdisciplinary team of specialists. [8,9]

The Day Hospital treatment is performed in a small group under a structured program, and includes socio-therapeutic and psychoeducation groups, work therapy, music therapy, cognitive behavioural therapy, bibliotherapy, and film therapy with the daily ability of individual psychotherapy. The purpose is to include the patient in the psychotherapeutic and socio-therapeutic procedures of treatment, supporting the greatest possible level of independence [10,11]. The group therapy approach that is being used at Day Hospital has the purpose for patients to understand and control their illness and symptoms, realize the function and importance of taking medications and learn how to avoid the stressors that can cause a mental health decompensation $[10,12,13]$. The aim of this research was to compare potential differences in the sociodemographic and clinical characteristics of participants diagnosed with schizophrenia, treated stationary and at Day Hospital. A research hypothesis was that the participants treated only at Day Hospital prior to current treatment were less frequently hospitalised compared to those participants treated only stationary. 


\section{Participants and methods}

\section{Participants}

This prospective comparative study included 60 patients aged 18 to 55, including male and female patients, who meet the criteria for inclusion into the study, and were having a treatment at the time of data collection. The inclusion criterion for participation in this study was the diagnosis of schizophrenia, according to ICD-10 criteria. The study was conducted in the period from $1^{\text {st }}$ of April to $1^{\text {st }}$ of August 2018. Within this period thirty participants were randomised between those who had an acutely deteriorated mental state (acute schizophrenia) and were in inpatient ward at the time of data collection. The first group of participants was treated only stationary. The other group of thirty participants were randomised between those who were at the time of data collection treated at Day Hospital and there was no inpatient treatment in their history.

Patients with severe somatic or neurological illnesses (those requiring chronic medical treatment and those whose illness is not under adequate symptom control) were not included in the study.

The examiner interviewed potential participants according to ICD-10 criteria, also explaining the purpose and process of the research while maintaining confidentiality of data, and participants could at any time drop out of research and those who dropped out were excluded of research. The participant signed a form of informed consent if he agreed to participate in the research and fully understood the content of the form. Participation in the research was anonymous and voluntary.

\section{Study design}

The research has been approved by the Ethics Committee of University Clinical Hospital Center Sestre milosrdnice. In the first week of treatment, each participant fulfilled structured questionnaire of the sociodemographic and clinical characteristics for persons with schizophrenia which was created for the purpose of this research.

The first part of the questionnaire contained questions about sociodemographic features: gender, age, marital status, parental status, degree of education, work status and business ability. The second part of the questionnaire included clinical features: age at the time of treatment, duration of treatment, number of hospitalizations and day hospital treatments, number of days of hospitalization, questions of psychiatric heredity, involuntary hospitalization, suicidal attempts and aggressive behaviour and the use of antipsychotic medication, especially long-acting preparations.

The data were processed using the Statistical Package for the Social Sciences IBM SPSS Statistic 20. (SPSS for Windows 20.0, SPSS, Chicago, IL, USA). Statistical methods of data processing were used, in accordance with the established research problem.

\section{Results}

The study included 60 participants with schizophrenia randomly selected over a four month period. Out of a total of 30 inpatients, 17 were female and 13 were male participants, while 18 female and 12 male participants with schizophrenia were treated at Day Hospital, with no statistically significant difference in gender representation between the two groups. 
Furthermore, participants were divided into four categories according to age: from 18 to 30 years, from 31 to 40 years, from 41 to 50 years, from 51 to 55 years. The majority of inpatients treated were inpatients between the ages of 41 and 55, 22 or $77.3 \%$. In contrast to the Department, where only $6.7 \%$ of participants were treated in the youngest age group, $40 \%$ of the participants at Day Hospital were among the youngest age group, 18 to 30 years, while in the other age groups were the equal representation, 20\%. No statistically significant difference was found between the two groups. The youngest participant was 21 years old and the oldest was 55 years old. No statistically significant difference was found between the two groups either in terms of marital status and parenthood, namely, equal number of participants in marriage or extra marriage union, $20 \%$ in both groups, and the same number of singles. Of the 30 treated inpatients, five had one child, while four had two children, as opposed to Day Hospital, where four had one child, four had two children, and one had three children. Thus, approximately one third of the participants had children in both groups, which is not statistically significant.

Regarding education and work status, the inpatients mostly had secondary education, $80 \%$ of them, while those treated at Day Hospital had equally high school education $56.7 \%$ and higher or high level of professional qualification $43.3 \%$. In addition, $36.7 \%$ of the inpatients were permanently retired, as opposed to only $10 \%$ of those treated at Day Hospital. There were $23.3 \%$ employed inpatients, while at Day Hospital there were $30 \%$. No statistically significant differences were identified in these parameters, nor did during the examination of legal capacity. All participants treated at Day Hospital had adequate legal competence, but $10 \%$ of the inpatients did not have it, and in some segments of legal competence they had a legal guardian appointed.

The age at the beginning of treatment was also divided into four categories: from 15 to 25 years, from 26 to 35 years, from 36 to 45 years, from 46 to 55 years, and the average age in the group of inpatients was from 26 to 35 years (53.3\% of participants), while at Day Hospital for schizophrenia the younger age group prevails, i.e. from 15 to 25 years (40\% of participants). There was also no statistically significant difference.

The total duration of treatment was also divided into four categories: up to one year, one to five years, six to ten years, and ten years and longer. Participants treated at the Day Hospital were mainly in the early stages of the illness, that is, in the groups up to five years of treatment, $63.3 \%$, while $67.7 \%$ of the treated inpatients had a duration of treatment longer than ten years, according to which the specified parameters are not statistically significant.

The average hospitalization rate of patients treated at Day Hospital was 2.23 and 5.93 inpatients, which is statistically significantly higher concerning the patients treated at Day Hospital $(t=3.763$; $=0.001)$. The average number of hospitalization days for inpatients was 28.03, while for those participants treated at Day Hospital it was 25.43 days, and there is no statistically significant difference.

Only two people were involuntary treated at Day Hospital (6.7\%), while there were five among inpatients $(16.7 \%)$ for the duration of the illness prior to the current hospitalization. In addition, $63.3 \%$ of participants treated at Day Hospital were more regular at appoint- 
ments compared to inpatients, among which $36.7 \%$ were regular. To occasional appointments come $23.3 \%$ of inpatients and $13.3 \%$ of the participants treated at Day Hospital, while 7 participants treated at Day Hospital or $23.3 \%$ do not come for appointments compared to $40.0 \%$ or 12 inpatients. Although certain trends are apparent, statistical significance is not established in this respect.

Also, no significant differences in the compared parameters were observed with regard to the existence of psychiatric heredity, which was positive in $36.7 \%$ of the patients treated in Day Hospital and in $53.3 \%$ of inpatients.

During the course of the illness, and prior to the current hospitalization and participation in this study, it was found that just over a quarter or $26.7 \%$ of the patients treated at Day Hospital had previously attempted sui- cide, opposite to $10 \%$ in the group of inpatients. On the other hand, $20 \%$ of those treated at the Day Hospital and $46.7 \%$ of those treated inpatients reported the aggressive behaviour towards other people, healthcare staff or hospital inventory. Participants stated verbal aggression as the most common form of aggression.

Out of a total of 30 inpatients, 19 or $63.3 \%$ were treated with long-acting injectable antipsychotics, and the distribution of administering long-acting preparations was shown in Figure 1.

A significant number, or $80 \%$ of the patients treated at Day Hospital were treated with long-acting form of antipsychotics. The distribution of long-term antipsychotic preparations received by patients treated at Day Hospital for schizophrenia is shown in Figure 2.

Inpatient treatment

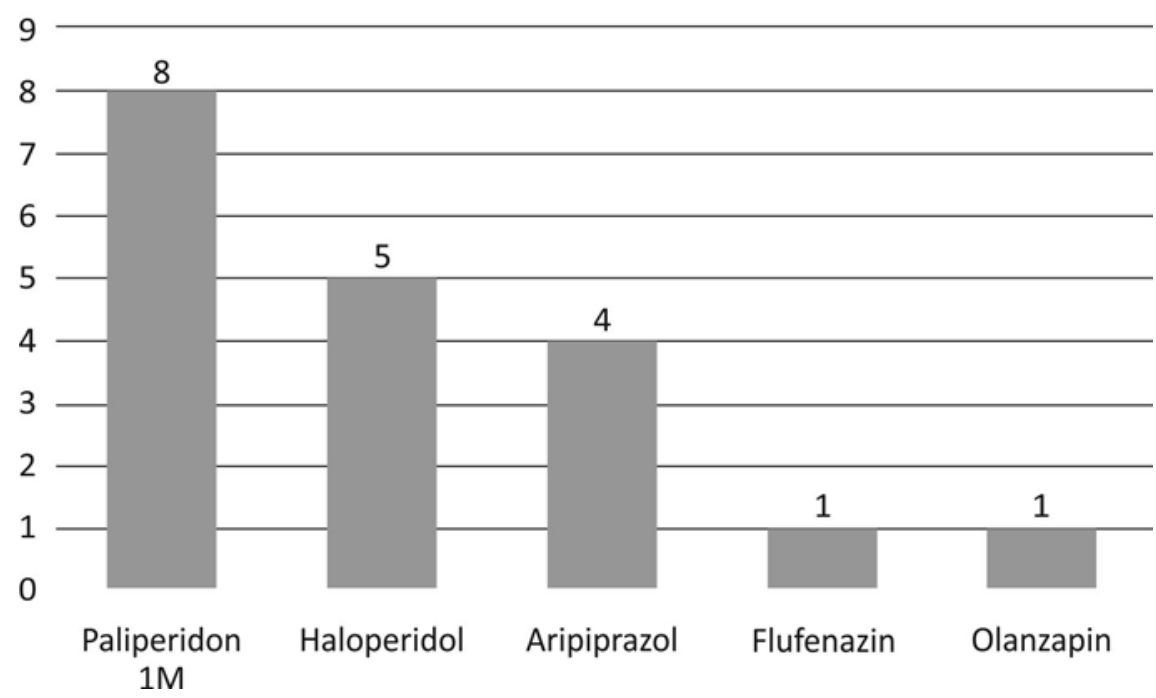

Figure 1. Distribution of administered long-acting antipsychotic preparations in inpatients 
Day Hospital

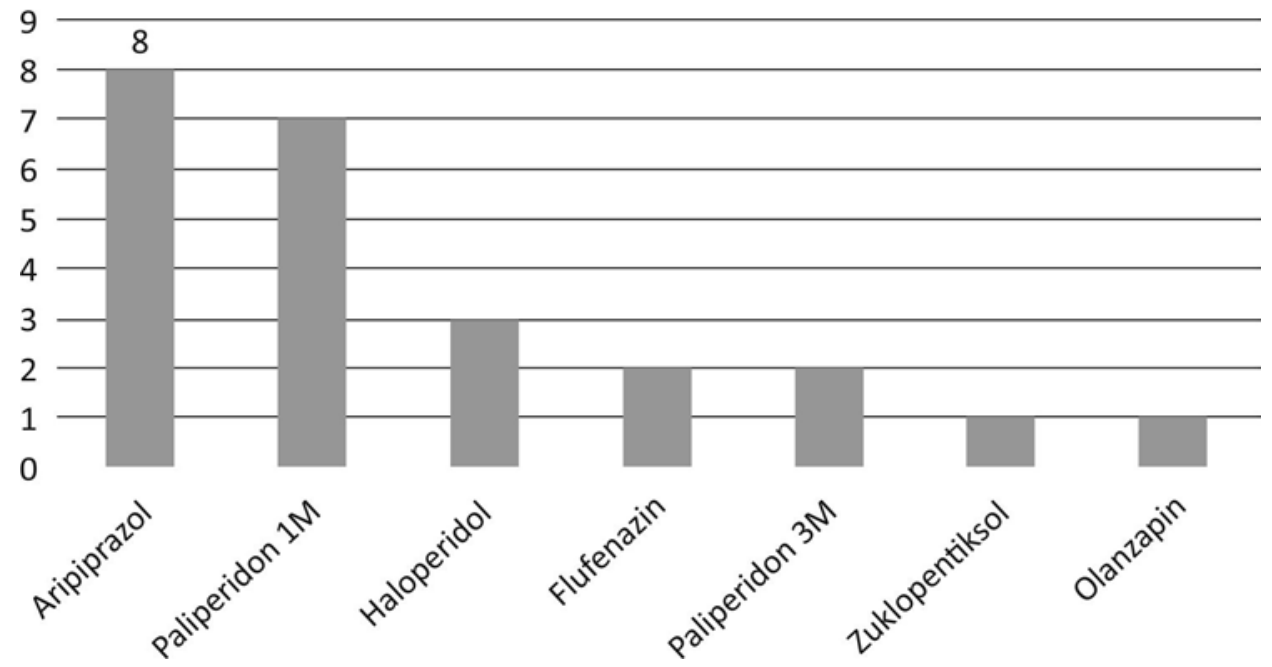

Figure 2. Distribution of administered long-acting antipsychotic preparations in patients treated at the Day Hospital

\section{Discussion}

This study compared two groups of patients with schizophrenia, one group treated with inpatient treatment, the other group treated at Day Hospital for schizophrenia, and examined similarities and differences in sociodemographic and clinical characteristics of the two groups.

The above mentioned questionnaire found similar representation of schizophrenia by gender in both groups, as confirmed by earlier findings [14], although some studies indicate a slightly more frequent occurrence of schizophrenia in men compared to women (1.4: 1) [15].

Comparing different characteristics of schizophrenia between gender, women are more likely to get married than men [16].
But, in our study, marital and parenting status and single status in both groups coincided. Also, one third of the participants in both groups have descendants. According to Jablensky and colleagues, women diagnosed with schizophrenia typically have fewer descendants than non-schizophrenic patients, however, this difference is less pronounced in women than in men [17].

Furthermore, the level of education was examined, and in both groups $73 \%$ of participants completed secondary education and $15 \%$ of the participants have college education. Such information is not surprising, given that schizophrenia as a disease affects a person's cognitive functioning, which can consequently affect educational status [18], and ultimately, work function [19]. Therefore, patients treated at Day Hospital, 
although not statistically significant, have better work performance compared to inpatients.

Recent studies show however, that the employment rate in patients with schizophrenia is generally lower than the employment rate in patients with other psychotic disorders and is about 6 to 7 times lower than in the healthy population, making it the largest group benefiting from financial support due to disability. This also results in a lower socioeconomic status [20-22]. All patients treated at Day Hospital had assessed legal competence, which is probably related to a shorter overall duration of the illness, as well as stronger psychosocial support and education on the possibilities of recovery and inclusion in daily life. On the other hand, $10 \%$ of inpatients had some aspects of their legal competence taken away and a legal guardian appointed. Although statistically insignificant, however, a slightly larger number of participants with a dispossessed legal competence can be a consequence of longer treatment duration, that is, less compliance and consequently higher number of hospitalizations, which are the differences between the two groups.

Comparing the results of ages when the treatment started, more than half of the inpatients ranged in age from 26 to 35 years, while among those treated at Day Hospital, the age of onset of schizophrenia treatment was lower. Most participants ranged in age from 15 and 25 years, which is in favour with an epidemiological study of the early incidence of schizophrenia by Hafner and colleagues [23]. Participants treated at Day Hospital are mainly in the early stage of the illness, that is, they fall into a subset with duration of up to five years, while the inpatients are generally treated for more than ten years, which emphasizes the importance of timely detection and treatment.

Accordingly, the number of hospitalizations of patients treated at Day Hospital was considerably lower compared to inpatients which confirmed the hypothesis of this study. Moscowitz and colleagues emphasize that day-care psychiatric treatment is comparable to inpatient treatment and that such treatment effects may be longer lasting than those obtained under more traditional treatment setting [13]. Typically, inpatient treatment is generally needed for short periods of time which allows for psychotic decompensation to be intensively managed [24]. After that there is a need to include and reintegrate patient in his primary social setting. Recent study claim there has been a decline in the number of hospitalizations and days spent in hospital associated with the diagnosis of schizophrenia [25]. As a transition step between inpatient and outpatient treatment frequently are used day care programs [8]. According to the previously published data on treatment efficacy at the Day Hospital which indicate a faster withdrawal of symptoms, lower treatment costs as opposed to inpatient treatment [5], and fewer hospitalizations for patients treated at Day Hospital and longer illness remission after treatment [24,26].

Furthermore, data from family studies indicate the importance of genetic predisposition and the increased incidence of schizophrenia among relatives [27]. It has been known from earlier studies that the treatment of schizophrenia in people with psychiatric heredity has a worse prognosis [28] and that there is a greater likelihood of inpatient treatment, which is consistent with our research.

In addition, suicide rates are more common, with an estimated 20 to $40 \%$ of patients with schizophrenia attempting suicide 
during their lifetime, while about half of that number attempt to succeed $[29,30]$. This is in line with the results of our study, namely, $26.7 \%$ treated at Day Hospital tried suicide at some stage of the disorder, as opposed to inpatients where the suicide attempted 10\% of participants. Although a difference in percentage was observed between the groups, it was not statistically significant, but it does indicate a certain trend that may be explained by a greater degree of insight into the condition and illness of the patients treated at Day Hospital compared to inpatients who have a more hospitalizations and illness relapse, and consequently less insight [31]. Schizophrenia is also associated with an increased risk of aggressive behaviour [32,33], and in our study, twice as many inpatients in one of the periods of acute exacerbation of illness manifested aggressive behaviour compared to those participants treated at the Day Hospital.

Lack of insight into the illness is considered as an indicator of the severity of schizophrenia, directly related to its worse course and ultimately its outcome. Thus, it turned out that the participants treated at Day Hospital were more regular at appointments than inpatients, but with no statistically significant difference. Weighill and colleagues found that patients who did not respond to the first follow-up examination at the end of hospital treatment were very likely to terminate psychiatric treatment, with relapse and rehospitalisation being known to be a consequence of withdrawal [34].

One of the significant factors in the prevention of schizophrenia relapse is the use of antipsychotics, and to better compliance helps the use of long-acting antipsychotics, which received over a half of the inpatients, compared to almost the majority of the pa- tients treated at Day Hospital. Although no statistically significant difference was found in the distribution of long-acting antipsychotics used in the comparable patient groups, we can assume that patients treated at Day Hospital were more aware of the need to take long-acting antipsychotics and their usefulness, resulting in a lower relapse rate and a better outcome of the disorder, as discussed by a number of studies [35-38].

The main limitation of this study is the relatively small sample size, which therefore does not allow generalization of these results to the entire population of schizophrenia in Republic of Croatia, and further research is needed on a larger cause and through a longer period of time to obtain more representative research results. The study included participants diagnosed with schizophrenia, but not acute psychotic disorder, which is relatively common in our hospital settings. Also, the participants provided self-assessment within the questionnaire without any external validation of data.

The use of categorical divisions in the processing of sociodemographic data, however, may have influenced the fact that no statistically significant correlation was found on these issues. The impact of the other parameters studied on the number of hospitalizations among the examined patient groups has not been demonstrated in this study.

The hypothesis of this research was confirmed, as participants with schizophrenia treated at the Day Hospital setting had a lower number of hospitalisations and consequently longer periods of remission than inpatients. However, as this was a cross sectional study, data collected was before the point of measurement. Furthermore, by comparing sociodemographic and clinical characteristics we can observe their influence on the 
higher incidence of repeated hospitalizations in inpatients.

It was observed that the participants treated at the Day Hospital were younger, with a higher education level, more able to work and involved in psychiatric treatment at the early stages of the illness, which aids in achieving better personal and social functioning, as well as to provide adequate guidance in daily life. This suggests a higher level of life quality compared to the inpatients. In view of the above, partial forms of hospitalization (especially Day Hospital) should be pursued as much as possible in order

\section{References}

1. Bobes J, Garcia-Portilla MP, Bascaran MT, Saiz PA, Bouzoño M. Quality of life in schizophrenic patients. Dialogues Clin Neurosci. 2007;9:215-26.

2. Wunderink L, Nieboer RM, Wiersma D, Sytema $\mathrm{S}$, Nienhuis FJ. Recovery in remitted first episode psychosis at 7 years of follow-up of an early dose reduction/discontinuation or maintenance treatment strategy: long-term follow-up of a 2-year randomized clinical trial. JAMA Psychiatry. 2013;70:913-20.

3. Lehman AF, Lieberman JA, Dixon LB, McGlashan TH, Miller AL,Perkins DO, et al. Practice guideline for the treatment of patients with schizophrenia, second edition. Am J Psychiatry. 2004;161(Suppl 2):1-56.

4. Alptekin K, Ucok A, Ayer A, Unal A, Erol A, Ensari $\mathrm{H}$, et al. Treatment Guidelines for Patients with Schizophrenia or Psychotic Disorder who are Hospitalized in a Psychiatry Clinic. Klinik Psikofarmakoloji Bülteni. 2014;24:3276-88.

5. Addington D, Anderson E, Kelly M, Lesage A, Summerville C. Canadian Practice Guidelines for Comprehensive Community Treatment for Schizophrenia and Schizophrenia Spectrum Disorders. Can J Psychiatry. 2017;62:662-72. to reduce the stress of stationary treatment and increase the quality of life of patients with schizophrenia. Eventually, working on improving the organisation of Day care programs could strengthen community treatment of patients with schizophrenia in Republic of Croatia.

\section{Acknowledgements}

None.

\section{Conflicts of interest}

None to declare.
6. Chien WT, Leung SF, Yeung FK, Wong WK. Current approaches to treatments for schizophrenia spectrum disorders, part II: psychosocial interventions and patient-focused perspectives in psychiatric care. Neuropsychiatr Dis Treat. 2013;9:1463-81.

7. Curral R, Lopes R, Silveira C, Norton A, Domingues I, Lopes F, et al. Forty years of a psychiatric day hospital. Trends Psychiatry Psychother. 2014;36:52-8.

8. Shek E, Stein AT, Shansis FM, Marshall M, Crowther R, Tyrer P. Day hospital versus outpatient care for people with schizophrenia. Cochrane Database Syst Rev. 2009;4:CD003240.

9. Herz MI, Endicott J, Spitzer RL, Mesnikoff A. Day versus inpatient hospitalization: a controlled study. Am J Psychiatry. 1971;127:137182.

10. Altamura AC, Fagiolini A, Galderisi S, Rocca P, Rossi A. Integrated treatment of schizophrenia. J Psychopathol. 2015;21:168-93.

11. Pilling S, Bebbington P, Kuipers E, Garety P, Geddes J, Orbach G, et al. Psychological treatments in schizophrenia: I. Meta - analysis of family intervention and cognitive behaviour therapy. Psychol Med. 2002;32:763-82. 
12. Hirsch SR, Platt S, Knights A, Weyman A. Shortening hospital stay for psychiatric care: effect on patients and their families. Br Med J. 1979;1:442-6.

13. Moscowitz IS. The effectiveness of day hospital treatment: A review. J Community Psychol. 1980;8:155-64.

14. Wyatt RJ, Alexander RC, Egan MF, Kirch DG. Schizophrenia, just the facts. What do we know, how well do we know it? Schizophr Res. 1988;1:3-18.

15. Abel KM, Drake R, Goldstein JM. Sex differences in schizophrenia. Int Rev Psychiatry. 2010;22:417.

16. Ochoa S, Usall J, Cobo J, Labad X, Kulkarni J. Gender Differences in Schizophrenia and First-Episode Psychosis: A Comprehensive Literature Review. Schizophr Res Treatment. 2012;2012:916198.

17. Thara R, Srinivasan TN. Outcome of marriage in schizophrenia. Soc Psychiatry Psychiatr Epidemiol. 1997;32:416-20.

18. Jablensky A, Kirkbride JB, Jones PB. Schizophrenia: The epidemiological horizon. In: Weinberger DR, Harrison PJ (Eds.). Schizophrenia. WileyBlackwell. 2011;185-225.

19. Mosiołek A, Gierus J, Koweszko T, Szulc A. Cognitive impairment in schizophrenia across age groups: a case-control study. BMC Psychiatry. 2016;16:37.

20. Vargas G, Strassnig M, Sabbag S, Gould F, Durand D, Stone L, Patterson TL, Harvey PD. The course of vocational functioning patients with schizophrenia: Re-examining social drift. Schizophr Res Cogn. 2014;1:41-6.

21. Aro S, Aro H, Keskimäki I. Socio-economic mobility among patients with schizophrenia or major affective disorder. A 17-year retrospective followup. Br J Psychiatry. 1995;166:759-67.

22. Dohrenwend BP. Socioeconomic Status (SES) and Psychiatric Disorders. Soc Psychiatry Psychiatr Epidemiol. 1990;25:41- 7.

23. Gureje O, Herrman H, Harvey C, Morgan V, Jablensky A. The Australian National Survey of Psychotic Disorders: profile of psychosocial disability and its risk factors. Psychol Med. 2002;32:639-47.

24. Marshall M, Crowther R, Sledge WH, Rathbone J,Soares-Weiser K. Day hospital versus admission for acute psychiatric disorders. Cochrane Database Syst Rev. 2011;7:CD004026.

25. Štrkalj Ivezić S, Jukić V, Štimac Grbić D, Ćelić I, Brečić P, Silobrčić Radić M i sur. Organizacija liječenja oboljelih od mentalnih poremećaja u Republici Hrvatskoj. Acta med Croatica. 2018;72:179-87.

26. Häfner H, Maurer K, Löffler W, Fätkenheuer B, an der Heiden W, Riecher-Rössler A, et al. The epidemiology of early schizophrenia: influence of age and gender on onset and early course. Br J Psychiatry Suppl. 1994;23:29-38.

27. Washburn SL, Vannicelli M, Longabaugh R, Scheff BJ. A controlled comparison of psychiatric day treatment and inpatient hospitalization. J Consult Clin Psychol. 1976;44:665-75.

28. Gottesman II, Wolfgram DL. Schizophrenia genesis: The origins of madness. In: A series of books in psychology. New York: Freeman; 1991.

29. Jobe TH, Harrow M. Long-term outcome of patients with schizophrenia: a review. Can Psychiatry. 2005;50:892-900.

30. Altamura AC, Bassetti R, Bignotti S, Pioli R, Mundo E. Clinical variables related to suicide attempts in schizophrenic patients: a retrospective study. Schizophr Res. 2003;60:47-55.

31. Pompili M, Amador XF, Girardi P, Harkavy-Friedman J, Harrow M, Kaplan K,et al. Suicide risk in schizophrenia: learning from the past to change the future. Ann Gen Psychiatry. 2007;6:10.

32. Lincoln TM, Lüllmann E, Rief W. Correlates and Long-Term Consequences of Poor Insight in Patients with Schizophrenia. A Systematic Review. Schizophr Bull. 2007;33:1324-42.

33. Weiss EM. Neuroimaging and Neurocognitive Correlates of Aggression and Violence in Schizophrenia. Scientifica (Cairo). 2012;2012:158646.

34. Lotar Rihtarić M, Vrselja I, Jandrić Nišević A. Relationship between Alcohol Consumption and Violent Offending: Personality as a Contributing Factor. Alcoholism and Psychiatry research. 2016;52:105-14.

35. Weighill VE, Hodge J, Peck DF. Keeping appointments with clinical psychologists. Br J Clin Psychol. 1983;22:143-44.

36. Ascher-Svanum H, Faries DE, Zhu B, Ernst FR, Swartz MS, Swanson JW. Medication adherence and long-term functional outcomes in the treatment of schizophrenia in usual care. J Clin Psychiatry. 2006;67:453-60.

37. Gerlach J. Depot neuroleptics in relapse prevention: advantages and disadvantages. Int Clin Psychopharmacol. 1995;9:17-20.

38. Pandarakalam JP. The long-acting depot antipsychotic drugs. Hosp Med. 2003;64:603-8. 


\section{Usporedba sociodemografskih i kliničkih karakteristika shizofrenih bolesnika liječenih stacionarno i u dnevnoj bolnici}

Sažetak - Suvremeni koncept liječenja shizofrenije teži postizanju funkcionalne remisije, smanjenju broja i duljine hospitalizacija i poboljšanju kvalitete života pacijenata. Cilj ove studije bio je identificirati i usporediti sociodemografske i kliničke karakteristike ispitanika oboljelih od shizofrenije koji su liječeni stacionarno i onih liječenih putem dnevne bolnice. Ovo istraživanje u trajanju od četiri mjeseca, obuhvaćalo je nasumično odabranih 60 ispitanika sa shizofrenijom u dobi od 18 do 55 godina, koji su bili podijeljeni u dvije skupine. Prva skupina od 30 ispitanika liječena je samo stacionarno, a ostalih 30 ispitanika liječeno je samo u dnevnoj bolnici. Ispitanici su ispunili Upitnik o sociodemografskim i kliničkim karakteristikama koji je stvoren za potrebe ovog istraživanja. Rezultati su pokazali da su ispitanici liječeni u dnevnoj bolnici mlađe životne dobi, višeg stupnja obrazovanja, radno sposobniji te su uključeni u psihijatrijski tretman već u ranim fazama bolesti. Nadalje, zamijećen je manji broj rehospitalizacija ispitanika liječenih u dnevnoj bolnici u odnosu na ispitanike liječene stacionarno, što je bilo statistički značajno ( $t=3,763 ; p=0,001)$, a znači manji broj akutnih epizoda bolesti i dulja razdoblja remisije. Navedeno pridonosi boljem osobnom i socijalnom funkcioniranju, kao i adekvatnijem snalaženju u svakodnevnom životu, a time podrazumijeva višu razinu kvalitete života u usporedbi s ispitanicima liječenim stacionarno.

Ključne riječi: shizofrenija, dnevna bolnica, stacionarno liječenje, grupna psihoterapija 
